Differentiation of hPSCs to hypothalamic neurons

\section{VERSION 1}

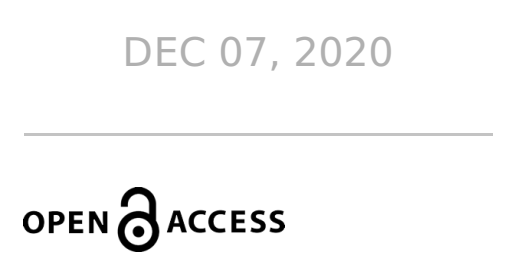

DOI:

dx.doi.org/10.17504/protocol s.io.bn8qmhvw

Protocol Citation: Cortina Chen, Iman Mali, Florian T Merkle 2020. Differentiation of hPSCs to hypothalamic neurons. protocols.io https://dx.doi.org/10.17504/p rotocols.io.bn8qmhvw

License: This is an open access protocol distributed under the terms of the Creative Commons Attribution License, which permits unrestricted use, distribution, and reproduction in any medium, provided the original author and source are credited

\section{Protocol status: In} development We are still developing and optimizing this protocol

Created: Oct 29, 2020

Last Modified: Dec 07, 2020

\section{PROTOCOL integer ID:} 44016

Keywords: Differentiation, hPSCs, hypothalamic neurons

\section{(3) Differentiation of hPSCs to hypothalamic neurons V.1} $\rightarrow$ In 1 collection

\section{Cortina Chen ${ }^{1}$, Iman Mali $^{1}$, Florian T Merkle ${ }^{1}$}

${ }^{1}$ Wellcome-MRC Institute of Metabolic Science, University of Cambridge, Cambridge, CB2 OQQ, United Kingdom

Neurodegeneration Method Development Community

Tech. support email: ndcn-help@chanzuckerberg.com

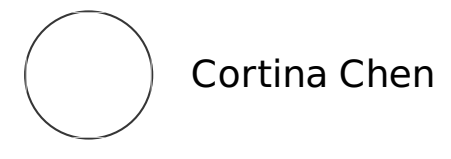

\section{ABSTRACT}

This protocol is about Differentiation of hPSCs to hypothalamic neurons.

\section{ATTACHMENTS \\ Differentiation_of_hPSCs_ \\ to_hypothalamic_neurons.}

$$
\text { pdf }
$$

\section{MATERIALS}

\section{Materials}

\section{$881 \mathrm{M} \mathrm{CaCl} 2$ Merck MilliporeSigma (Sigma-Aldrich) Catalog \#21115}

88 L-Ascorbic acid Merck MilliporeSigma (Sigma-Aldrich) Catalog \#A4403

88 B-27 Supplement Gibco - Thermo Fischer Catalog \#17504044

89 Animal-Free Recombinant Human/Murine/Rat BDNF peprotech Catalog \#AF88 450-02

88 CHIR99021 Cell Guidance Systems Catalog \#SM13-10

88 DAPT Merck MilliporeSigma (Sigma-Aldrich) Catalog \#D5942

88 DPBS, no calcium, no magnesium Thermo Fisher Catalog \#14190144

$\&$ DMEM/F-12, GlutaMAX ${ }^{\mathrm{TM}}$ Supplement Thermo Fisher Catalog \#31331028

88 DMEM/F-12, HEPES, no phenol red Thermo Fisher Catalog \#11039021

$\& 8$ DNase Vial (D2) Worthington Biochemical Corporation Catalog \#LK00317 Geltrex ${ }^{\mathrm{TM}}$ LDEV-Free Reduced Growth Factor Basement Membrane Matrix Therm
Fisher Catalog \#A1413202

88 GABA Tocris Catalog \#0344

88 GlutaMAX Gibco - Thermo Fisher Catalog \#35050038 
Stemolecule LDN-193189 Reprocell Catalog \#04-0074

8 LM 22A4 Tocris Catalog \#4607

88

MEM Non-Essential Amino Acids Solution (100X) Thermo Fisher

Scientific Catalog \#11140035

88 N2 supplement Gibco - Thermo Fisher Catalog \#17502048

88 Neurobasal-A Medium Thermo Fisher Scientific Catalog \#10888022

88 NKH 477 Merck MilliporeSigma (Sigma-Aldrich) Catalog \#N3290

88

PDS Kit Papain Vial Worthington Biochemical Corporation Catalog \#LK003176

PD 0332991 isethionate Merck MilliporeSigma (Sigma-Aldrich) Catalog \#PZ0199

88

Penicillin-Streptomycin (10,000 U/mL) Thermo Fisher Scientific Catalog

\#15140122

88 Purmorphamine Merck Millipore (EMD Millipore) Catalog \#540220

88 SB 431542 hydrate Merck MilliporeSigma (Sigma-Aldrich) Catalog \#S431

89 MilliporeSigm Calbiochem Smoothened Agonist SAG Fisher Scientific Catalo \#56-666-01MG

88 Sodium Bicarbonate 7.5\% solution Thermo Fisher Catalog \#25080060

88 StemFlex $^{\text {TM }}$ Medium Thermo Fisher Scientific Catalog \#A3349401

88

Trypan Blue Stain (0.4\%) for use with the Countess ${ }^{\mathrm{TM}}$ Automated Cell

Counter Thermo Fisher Scientific Catalog \#T10282

\&8 Stemolecule XAV939 Reprocell Catalog \#04-0046

$8 \%$

Y-27632 dihydrochloride (Rock Inhibitor) Contributed by users Catalog \#DNSK-KI-15-02

\section{Media and Reagents}

StemFlex

\begin{tabular}{|l|l|}
\hline Name & $\begin{array}{l}\text { Volu } \\
\mathrm{me}\end{array}$ \\
\hline StemFlex basal medium & $\begin{array}{l}450 \\
\mathrm{~mL}\end{array}$ \\
\hline StemFlex supplement & $50 \mathrm{~mL}$ \\
\hline
\end{tabular}

N2B27

\begin{tabular}{|l|l|}
\hline Name & $\begin{array}{l}\text { Volu } \\
\mathrm{me}\end{array}$ \\
\hline Neurobasal-A & $\begin{array}{l}500 \\
\mathrm{~mL}\end{array}$ \\
\hline DMEM/F12 with GlutaMAX & $\begin{array}{l}500 \\
\mathrm{~mL}\end{array}$ \\
\hline
\end{tabular}




\begin{tabular}{|l|l|}
\hline Glutamax & $10 \mathrm{~mL}$ \\
\hline Sodium bicarbonate & $10 \mathrm{~mL}$ \\
\hline MEM Nonessential amino acids & $5 \mathrm{~mL}$ \\
\hline Ascorbic acid (200 mM) & $1 \mathrm{~mL}$ \\
\hline Penicillin-streptomycin & $10 \mathrm{~mL}$ \\
\hline Sterile filter, then add the following supplements: & \\
\hline B27 supplement & $10 \mathrm{~mL}$ \\
\hline N2 supplement & $5 \mathrm{~mL}$ \\
\hline
\end{tabular}

\section{$N 2 B 27+B D N F$ (maturation media)}

\begin{tabular}{|l|l|}
\hline Name & $\begin{array}{l}\text { Volu } \\
\mathrm{me}\end{array}$ \\
\hline N2B27 & $\begin{array}{l}500 \\
\mathrm{~mL}\end{array}$ \\
\hline BDNF $(100 \mu \mathrm{g} / \mathrm{mL}$ stock $)$ & $50 \mu \mathrm{L}$ \\
\hline
\end{tabular}

Trituration medium

\begin{tabular}{|l|l|}
\hline Name & Volume \\
\hline N2B27 + BDNF & $30 \mathrm{~mL}$ \\
\hline $\begin{array}{l}\text { Y-27632 dihydrochloride (Rho kinase } \\
\text { inhibitor; } 10 \mathrm{mM} \text { stock) }\end{array}$ & $30 \mu \mathrm{L}$ \\
\hline Dnase I (2 mg/mL stock; $5990 \mathrm{U} / \mathrm{mg})$ & $500 \mu \mathrm{L}$ \\
\hline
\end{tabular}

\section{Synaptojuice 1 (SJ1; enhanced maturation media)}

\begin{tabular}{|l|l|}
\hline Name & $\begin{array}{l}\text { Volu } \\
\mathrm{me}\end{array}$ \\
\hline N2B27 + BDNF & $\begin{array}{l}500 \\
\mathrm{~mL}\end{array}$ \\
\hline DAPT (50 mM stock) & \begin{tabular}{l}
$50 \mu \mathrm{L}$ \\
\hline PD0332991 (20 mM stock)
\end{tabular} \\
\hline $\mathrm{CaCl}_{2}$ & $\begin{array}{l}50 \mu \mathrm{L} \\
\mu \mathrm{L}\end{array}$ \\
\hline NKH477 (10 mM stock) & $\begin{array}{l}500 \\
\mu \mathrm{L}\end{array}$ \\
\hline CHIR99021 (20 mM stock) & $50 \mu \mathrm{L}$ \\
\hline GABA (300 mM stock) & $\begin{array}{l}500 \\
\mu \mathrm{L}\end{array}$ \\
\hline
\end{tabular}


Synaptojuice 2(SJ2; enhanced maturation media)

\begin{tabular}{|l|l|}
\hline Name & $\begin{array}{l}\text { Volu } \\
\mathrm{me}\end{array}$ \\
\hline N2B27 + BDNF & $\begin{array}{l}500 \\
\mathrm{~mL}\end{array}$ \\
\hline PD0332991 (20 mM stock) & $50 \mu \mathrm{L}$ \\
\hline $\mathrm{CaCl}_{2}$ & $\begin{array}{l}185 \\
\mu \mathrm{L}\end{array}$ \\
\hline CHIR99021 (20 mM stock) & $50 \mu \mathrm{L}$ \\
\hline LM22A4 (10 mM stock) & $50 \mu \mathrm{L}$ \\
\hline
\end{tabular}

\section{SAFETY WARNINGS}

(1) For hazard information and safety warnings, please refer to the SDS (Safety Data Sheet).

\section{BEFORE START INSTRUCTIONS}

Prepare Media and Reagents as described in section 'Materials'.

\section{Thawing of human pluripotent stem cell (hPSC) lines:}

1 Thaw an aliquot of 1:10 diluted Geltrex $8^{\circ}$ On ice or in the fridge.

2 Dilute aliquot 1:10 in ice-cold DMEM/F12 to a final concentration of 1:100.

3 To coat plates, add 1:100 diluted Geltrex to TC dish/plate and incubate for 01:00:00 at

\section{$8^{\circ} 37^{\circ} \mathrm{C}$, or Overnight at $8^{\circ} 4{ }^{\circ} \mathrm{C}$}


Note

Use \ $3 \mathrm{~mL}$ for a $10 \mathrm{~cm}$ dish or $₫ 1 \mathrm{~mL}$ for a well of a 6 well plate.

4 Aspirate Geltrex and rinse the dish/plate $1 \mathrm{x}$ with an equal volume of DPBS.

Note

Note: do not let the dish/plate dry out.

5 Add pre-warmed hPSC culture media: StemFlex with [M] 10 micromolar $(\mu \mathrm{M})$ Rock inhibitor

\ $10 \mathrm{~mL}$ per $10 \mathrm{~cm}$ dish, \ $2 \mathrm{~mL}$ per well of 6 well plate.

Note

Note: the dish/plate is ready to receive cells for plating.

6 Take vial cells from liquid nitrogen to TC room on dry ice.

7 Dip bottom half of vial into $8^{\circ} 37^{\circ} \mathrm{C}$ water bath and swirl until partially thawed (approximately 00:01:00 - 00:03:00, depending on volume of freeze).

8 Thoroughly spray vial with [M] $70 \%$ ethanol, and complete thaw by gently transferring prewarmed hPSC culture media into the partially thawed cells.

9 Transfer cells into a $15 \mathrm{~mL}$ V-bottom polypropylene tube with pre-warmed wash media. Wash residual cells out of vial with $\triangle 1 \mathrm{~mL}$ hPSC culture media 
10 Spin cells at $\because 9160 \times \mathrm{g}, 00: 03: 00$

○?

11 Aspirate media.

12 Re-suspend the pellet with $\triangle 10 \mathrm{~mL}$ hPSC culture media and mix well by gently pipet it up and down.

13 Spin at $\because: 160 \times \mathrm{g}, 00: 03: 00$

14 Aspirate media.

15 Re-suspend pellet with $\triangle 1 \mathrm{~mL}$ hPSC culture media . Dilute into appropriate volume depending on culture dishes/plates used.

16 Add and evenly distribute cells into dish/plate with pre-warmed hPSC culture media (from step 5).

17 Transfer to incubator, cells should attach over a few hours.

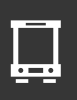

18 Change media the following day to StemFlex without Rock inhibitor. 
Note

Note: Withdrawal of Rock inhibitor will result in a notable change in morphology, from 'spikey' look cells with thin processes, to a smoother appearance. Some cell death may also occur.

\section{Hypothalamic Differentiation}

19 Coat 6-well or $10 \mathrm{~cm}$ plates with Geltrex for differentiation as described above.

20 Nearly confluent hPSCs are dissociated and re-plated for differentiation

Note

Note: Before induction of differentiation, hPSCs should lack obvious signs of differentiation or contamination, and be in a rapid growth phase.

21 Aspirate culture medium and briefly and gently wash cells in $8^{\circ}$ Room temperature DPBS.

22 Add $88^{\circ} 37^{\circ} \mathrm{C}$ TrypLE to cell culture, \ $1 \mathrm{~mL}$ per well in 6-well plate, $\triangle 5 \mathrm{~mL}$ per $10 \mathrm{~cm}$ plate.

23 Incubate cell culture for $00: 03: 00-(7) 00: 05: 00$ at $88^{\circ} 37^{\circ} \mathrm{C}$. After a 3 minute incubation, check to see if cells are detaching. Under a phase contrast microscope, the cells should start to round up and take on a phase-bright appearance, but not spontaneously detach from the plate. Once cultures adopt this appearance, gently suck up and dispel \& $100 \mu \mathrm{L}$ TrypLE solution with a P1000 pipette against the cells. They should easily dislodge and leave a small area devoid of cells. If cells do not dissociate easily, extend TrypLE digestion for another minute and repeat this test. 
Note

Note: Take care to avoid over-digestion, which can cause cell death.

24 Gently aspirate TrypLE.

25 To dissociate cells, add \ $1 \mathrm{~mL} /$ \ $5 \mathrm{~mL}$ hPSC culture media for a well of a 6 well/10 cm plate, and gently pipette this medium over the plate to detach cells and dissociate them to a single-cell suspension.

26 Collect cells in $15 \mathrm{ml} \mathrm{V-bottom} \mathrm{polypropylene} \mathrm{tube,} \mathrm{and} \mathrm{adjust} \mathrm{volume} \mathrm{with} \mathrm{hPSC} \mathrm{culture} \mathrm{media}$ (Total volume $=$ \& $10 \mathrm{~mL}$

Note

Note: This wash step dilutes residual TrypLE to slow further digestion.

27 Spin at $\because 160 \times \mathrm{g}$ for $00: 03: 00-300: 05: 00$ at $\AA^{\circ}$ Room temperature . Aspirate supernatant, re-suspend cells in $\triangle 10 \mathrm{~mL}$ hPSC culture media

28 Spin at $\because 160 \times \mathrm{g}$ for $00: 03: 00-300: 05: 00$ at $\mathscr{B}^{\circ}$ Room temperature Aspirate supernatant, re-suspend cells in hPSC culture media

Note

Note: These wash steps remove any remaining traces of TrypLE.

29 After re-suspending the cell pellet, adjust volume so that the suspension is visibly turbid, but not milky (approximately 1-5 x 106 cells $/ \mathrm{mL}$ ). 
In a $1.5 \mathrm{~mL}$ polypropylene tube, mix $\triangle 10 \mu \mathrm{L}$ of this cell suspension with

\ $10 \mu \mathrm{L}$ Trypan blue, transfer $\triangle 10 \mu \mathrm{L}$ of that mixture onto cell counting slide. Count cells with automated cell counter

31 Plate cells onto Geltrex-coated plates in hPSC culture media at a concentration of $1 \times 10^{5}$ cells per $\mathrm{cm}^{2}$ (corresponding to $9.5 \times 10^{5}$ cells per well of a 6 -well plate, or $5.5 \times 10^{6}$ cells per $10 \mathrm{~cm}$ plate). This density corresponds to approximately $80 \%$ confluence the following day. Ensure that cells are evenly distributed across the plate by gently shaking the plate left to right, then top to bottom before and after transferring it to the incubator.

Note

Note: If cells are sparser, wait until cells reach the desired density before starting the differentiation. Sparse or over-confluent cells will not pattern well.

32 If cells plated for differentiation are evenly distributed over the plate and at a density of approximately $75 \%$, start differentiation by washing cultures once with DPBS and adding Day 0 (D0) medium (see below). Every second day, make full medium changes as follows ( I $5 \mathrm{~mL}$ \ $6 \mathrm{~mL}$ per 6-well plate, \ $10 \mathrm{~mL}$ - Д $15 \mathrm{~mL}$ per $10 \mathrm{~cm}$ plate):

\section{Note}

Note: Observe cells daily for changes in morphology. From Days 0-2, the culture should reach confluence and cells should have a simple and uniform hPSC-like morphology. By Day 4 , cultures are highly compacted and cells adopt a more rounded appearance. Between Days 4 and 8 , the cultures take on a dense neuro-epithelial morphology with identifiable neural ridge-like structures. A neuro-epithelial morphology is still evident before passaging on Day 14.

32.1 Day O (DO): N2B27 + [M] 2 micromolar $(\mu \mathrm{M})$ XAV939 +

[M] 100 millimolar (mM) LDN-193189 + [M] 10 micromolar $(\mu M)$ SB431542

32.2 Day 2 (D2): N2B27 + [M] 2 micromolar ( $\mu$ M) XAV939 +

[M] 100 nanomolar $(\mathrm{nM})$ LDN-193189 + [M] 10 micromolar $(\mu \mathrm{M})$ SB431542 +
[M] 1 micromolar $(\mu \mathrm{M})$ SAG + [M] 1 micromolar $(\mu \mathrm{M})$ Purmorphamine


32.3 Day 4 (D4): N2B27 + [M] 1.5 micromolar $(\mu \mathrm{M})$ XAV939 + [M] 75 nanomolar (nM) LDN-193189 + [M] 7.5 micromolar $(\mu M)$ SB431542 + [M] 1 micromolar $(\mu M)$ SAG + [M] 1 micromolar $(\mu M)$ Purmorphamine

32.4 Day 6 (D6): N2B27 + [M] 1 micromolar $(\mu \mathrm{M})$ XAV939 + [M] 50 nanomolar (nM) LDN-193189 + [M] 5 micromolar $(\mu M)$ SB431542 + [M] 1 micromolar $(\mu \mathrm{M})$ SAG + [M] 1 micromolar $(\mu \mathrm{M})$ Purmorphamine

32.5 Day 8 (D8): N2B27 + [M] 0.5 micromolar $(\mu \mathrm{M})$ XAV939 + [M] 25 nanomolar (nM) LDN-193189 + [M] 2.5 micromolar $(\mu M)$ SB431542 + [M] 5 micromolar $(\mu \mathrm{M})$ DAPT

32.6 Day 10 (D 10): N2B27 + [M] 5 micromolar $(\mu \mathrm{M})$ DAPT

32.7 Day 12 (D12): N2B27 + [M] 5 micromolar $(\mu \mathrm{M})$ DAPT

32.8 Day 14 (D 14): N2B27 + [M] 5 micromolar $(\mu \mathrm{M})$ DAPT

\section{Neuronal Maturation}

33 Coat plates with Geltrex for maturation as described above (Optional: use a [M] $0.02 \%$ final Geltrex concentration to facilitate neuronal attachment and long term culture).

34 On Day 15, neural progenitors generated above are dissociated and re-plated to encourage neurogenesis and neuronal survival and maturation. 
Note

Note: Plate cells based on different experiment requirements/layout.

35 Wash cells gently with DPBS.

36 Prepare a mixture of TrypLE and Papain by mixing $810 \mathrm{~mL}$ TrypLE with 1 vial of Papain (140 U/vial). Papain aids in neuronal dissociation and will ensure significantly higher survival upon replating.

37 Add TrypLE with Papain to cells, \& $1 \mathrm{~mL}$ per well in 6 well plate, I $5 \mathrm{~mL}$ per $10 \mathrm{~cm}$ plate.

38 Incubate cell culture for $\circlearrowleft 00: 03: 00-00: 05: 00$ at $8^{\circ} 37^{\circ} \mathrm{C}$. After $\circlearrowleft 00: 03: 00$ of incubation, check to see if cells are detaching. Under a phase contrast microscope, the cells should start to round up and take on a phase-bright appearance, but not spontaneously detach from the plate. Once cultures adopt this appearance, gently suck up and dispel

\ $100 \mu \mathrm{L}$ TrypLE and Papain solution with a P1000 pipette against the cells. They should easily dislodge and leave a small area devoid of cells. If cells do not dissociate easily, extend TrypLE digestion for another minute and repeat this test.

Note

Note: Take care to avoid over-digestion, which can cause cell death and release of genomic DNA.

39 Gently aspirate TrypLE and Papain solution. 
40 To dissociate cells, add $\triangle 1 \mathrm{~mL} / \triangle 5 \mathrm{~mL}$ trituration medium for a well of a 6 well $/ 10 \mathrm{~cm}$

plate, and gently pipette this medium over the plate to detach cells and dissociate them to a single-cell suspension.

41 Collect cells in $15 \mathrm{~mL}$ V-bottom polypropylene tube, and adjust volume with trituration medium (Total volume $=$ \10 $\mathrm{mL}$ ).

42 Spin at $\because 160 \times \mathrm{g}$, Room temperature for $\circlearrowleft 00: 03: 00-\circlearrowleft 00: 05: 00$. Aspirate supernatant, re-suspend cells in $\triangle 10 \mathrm{~mL}$ trituration medium

43 Spin at $\because 160 \times \mathrm{g}$, Room temperature for 00 00:03:00 00:05:00. Aspirate supernatant, re-suspend cells in desired volume of trituration medium to enable plating at the desired density.

44 In a $1.5 \mathrm{~mL}$ polypropylene tube, mix $\triangle 10 \mu \mathrm{L}$ cell suspension with $\triangle 10 \mu \mathrm{L}$ Trypan blue , transfer $\& 10 \mu \mathrm{L}$ of the mixture onto cell counting slide. Count cells with automated cell counter.

Note

Note: If desired, cultures can be frozen at this point for later thawing as progenitors/immature neurons using the same procedure used for freezing hPSCs.

45 Plate cells onto Geltrex-coated plates in maturation media at a concentration of $1 \times 10^{5}$ cells per $\mathrm{cm}^{2}$ for cells maturing in N2B27 + BDNF (corresponding to $9.5 \times 10^{5}$ cells per well of a 6 well plate, or $5.5 \times 10^{6}$ cells per $10 \mathrm{~cm}$ plate)

Note

Note: Plate cells at a density of $3 \times 10^{5}$ cells per $\mathrm{cm}^{2}$ for cells maturing in the enhanced maturation media, Synaptojuice (SJ1/SJ2).

46 On Day 16, aspirate medium and feed with N2B27 + BDNF or Synaptojuice 1 (SJ1). 
47 On Day 17, aspirate medium and add twice the normal volume of Synaptojuice 1 (e.g. $\triangle 4$ mL per well of a 6 well plate, $\triangle 20 \mathrm{~mL}$ per $10 \mathrm{~cm}$ plate) for neuronal maintenance for 1 week. This larger volume helps ensure that neurons are exposed to a relatively constant supply of nutrients. After 1 week, maintain the mature neurons on N2B27 + BDNF or Synptojuice 2 (SJ2).

48 Change $[\mathrm{M}] 75 \%$ of media volume every second day. 